\title{
NEITHER A TRUISM NOR A TRIVIALITY: REPLY TO GRZANKOWSKI
}

\author{
HOWARD SANKEY \\ School of Historical and Philosophical Studies, University of Melbourne, AUSTRALIA \\ chs@unimelb.edu.au
}

\begin{abstract}
This is a reply to Alex Grzankowski's comment on my paper, 'To Believe is to Believe True'. I argue that one may believe a proposition to be true without possessing the concept of truth. I note that to believe the proposition $P$ to be true is not the same as to believe the proposition ' $P$ is true'. This avoids the regress highlighted by Grzankowski in which the concept of truth is employed an infinite number of times in a single belief.
\end{abstract}

Keywords: Belief $\bullet$ truth $\bullet$ believing true $\bullet$ Grzankowski

In 'To Believe is to Believe True', I sought to make a point about the nature of belief. I sought to show that when one believes a proposition one believes that the proposition is true. To believe just is to believe true. This is, I take it, a constitutive point about what it is to believe a proposition.

It was my expectation that the point I sought to make would be regarded as a truism or perhaps even a triviality. In any event, I think it likely that the point I sought to make is an analytic one. That is, it is analytic to the concept of belief that to believe is to believe true. I noted, though, that it is difficult to distinguish between being analytic to the concept of belief and being essential to the attitude of belief. I therefore left it open whether the point is to be expressed in terms of the analyticity of the concept or the essential nature of the mental state.

Given this, it is interesting to discover that the point may be regarded as neither a truism nor a triviality. For, as argued in his comment on my paper, Alex Grzankowski wishes to deny that to believe is to believe true. He provides two reasons for rejecting 
the claim that to believe is to believe true. In this rejoinder, I respond to the points made by Grzankowski in the order in which he makes them.

\section{II}

Grzankowski's first reason for rejecting my point is that belief is a "conceptual matter" in the sense that in order to have a particular belief it is necessary to "possess (and indeed deploy)" certain concepts. To use Grzankowski's example, to have the belief that dogs bark, one must possess both the concept DOG and the concept BARK. But, on the view that I propose, to believe that dogs bark is to believe it to be true that dogs bark. Given this, in order to believe that dogs bark, "one must also possess and indeed deploy the concept TRUE". But, Grzankowski claims, it is possible to believe that dogs bark without possessing the concept TRUE. One might believe that dogs bark without possessing "the sophistication to think thoughts concerning truth". My view, therefore "demands of all beliefs a level of cognitive sophistication not in fact demanded".

I have considerable sympathy for the claim that one may believe a proposition without possessing the concept of truth or, indeed, having the sophistication to have thoughts about truth. But I do not see this as a basis for denying that to believe is to believe true.

In order to show this, we need to consider two cases. In the first case, the person who believes a proposition $P$ possesses the concept of truth. In the second case, the person who believes the proposition $P$ does not possess the concept of truth.

In the first case, a person believes that $P$. On reflection, they may come to recognize that in believing that $P$ they thereby believe that $P$ is true. On further reflection, they may also recognize that if they did not believe that $P$ is true they would not believe that $P$. Indeed, they might even come to recognize that the concept of belief is the concept of believing true.

In the second case, a person who believes $P$ does not possess the concept of truth. In such a case, the person who believes $P$ is not able on reflection to recognize that in believing $P$ they thereby believe $P$ to be true. Does this mean that in believing $P$ they do not believe that $P$ is true? Surely not. If they do not believe $P$ is true, they do not believe $P$. All they have done is fail to recognize this because they lack the concept of truth.

It is worth noting in passing that a similar point may apply to the concept of belief itself. Consider someone who believes that dogs bark. As Grzankowski notes, such a person must possess the concept DOG and the concept BARK. Must they also possess the concept of belief? Is it necessary to possess the concept of belief in order to believe that dogs bark? This is not so obvious. It seems entirely possible that one 
might believe that dogs bark without possessing the concept of belief. Indeed, if one has any inclination to attribute beliefs to infants or to some non-human animals, this seems to be precisely what one should say.

\section{III}

Grzankowski's second reason for rejecting my point has two aspects which I shall deal with separately. In this section, I will consider the first aspect.

Having made the point that one may believe that $P$ while lacking the concept of truth, Grzankowski goes on to raise an objection based on the assumption that in order to be a believer one must have the concept of truth. Grzankowski interprets my view to be that to believe that $P$ is to believe the proposition ' $P$ is true'. Based on this interpretation, he then argues that I am committed to the view that in believing the simple proposition that $P$ a believer in fact believes a more complex proposition such as 'It is true that it is true that it is true that $P$ '. Here, in his own words, is how Grzankowski develops the point:

On Sankey's view, to believe that $P$ is to believe that $P$ is true. Call the proposition that $P$ is true ' $Q$ '. On Sankey's view, to believe that $P$ is to believe that $Q$. But to believe that $Q$ must be to believe that $Q$ is true. Call the proposition that $Q$ is true ' $R$ '. To believe that $R$ (which is the very same belief as the belief that $P$ ) must be to believe that $R$ is true. And on and on. But let us now unpack the belief that $R$ : it is, by simple substitutions of identicals, the very same belief as the belief that $P$ is true is true is true. On Sankey's view, this is the very same belief as the belief that $P$. On the very face of it this seems absurd. To believe that $P$ is not the same as to believe that $P$ is true is true is true. One is a relation to a simpler proposition than the other.

As Grzankowski understands my position, a person who believes the proposition $P$ thereby believes more complex propositions, such as the proposition that $P$ is true is true is true, which he takes to be absurd.

This objection is already undermined by my discussion in the previous section, since I do not grant the assumption that belief that $P$ requires possession of the concept of truth. However, the objection warrants consideration in its own right. I agree, of course, that it would be absurd to say that the belief that $P$ is the same belief as the belief that it is true that it is true that it is true that $P$ (or that $P$ is true is true is true). I also agree that to believe $P$ is not the same as to believe ' $P$ is true'. The former is the belief that $P$. The latter is the belief in the proposition ' $P$ is true'. ' $P$ ' and ' $P$ is true' are not the same proposition. To assert one is to assert $P$. To assert the other is to assert that $P$ is true.

But, despite agreement on this score, the objection is fatally flawed. It rests on a mistake closely akin to a use-mention confusion. For it erroneously equates using 
the concept of truth to explain what it is to believe a proposition $P$ with mentioning the proposition ' $P$ is true' in specifying the content of the belief. My view is not that to believe $P$ is to believe the proposition ' $P$ is true'. My view is that to believe $P$ is to believe $P$ to be true - i.e., to believe it to be true that $P$. Grzankowski's objection assumes the former interpretation, while my approach assumes the latter. In other words, I do not take the belief that $P$ to be precisely the same belief as the belief ' $P$ is true', as Grzankowski's argument requires. I hold, rather, that to believe $P$ is to believe $P$ true. The former interpretation allows for the iterated applications of 'is true' that Grzankowski's objection requires. The latter interpretation does not.

A more careful choice of words may help to bring this point out more clearly. I do not wish to say that to believe the proposition $P$ is to believe the proposition ' $P$ is true'. What I wish instead to say is that in believing $P$ one thereby believes it to be true. Another way of expressing this is to say that to believe $P$ is to believe-true $P$. It is not to say that to believe $P$ is to believe with respect to the proposition ' $P$ ' that it is true, but to believe-true $P$. Truth is in a sense embedded in belief, rather than being applied to the proposition in the way that the belief ' $P$ is true' applies 'is true' to the proposition $P$.

\section{IV}

The second aspect of Grzankowski's second reason builds on the first aspect. The concern Grzankowski raises is that the belief that $P$ is equivalent to belief in an infinite number of propositions, since the belief that ' $P$ is true' is subject to a certain kind of regress:

If to have the belief that $P$ is to have the belief that $P$ is true is true is true...then in order to believe that $P$ one must deploy her concept TRUE infinitely many times. And if it takes time to deploy a concept, then no belief could be had within a finite amount of time. But of course many beliefs are had in finite time, so those beliefs must not set us off on Sankey's regress.

The worry that Grzankowski expresses is that the idea that the belief that $P$ is the belief that ' $P$ is true' will give rise to a regress, in the course of which the concept of truth is applied an infinite number of times. It is not possible for one to apply a concept which requires infinite iterations in a finite amount of time. So, on my view, according to Grzankowski, believers must do something that cannot possibly be done.

I agree, of course, that what Grzankowski describes is impossible. But I deny that my view is committed to such a regress of iterations of the concept of truth. The

Principia 23(2): 361-365 (2019). 
reason that I deny this is for the same reason as the one presented in the previous section. I hold that to believe $P$ is to believe $P$ is true, not to believe ' $P$ is true'.

\section{V}

I conclude that Grzankowski's objections to the point that to believe is to believe true fail across the board. However, the objections have enabled me to provide a more careful articulation of the point that I sought to make in the original paper. I close with a challenge to Grzankowski: if you wish to deny that to believe is to believe true, the onus is surely on you to say what it is. An alternative positive proposal would be required to advance the discussion further. ${ }^{1}$

\section{References}

Grzankowski, A. 2019. To Believe is Not to Believe True: Reply to Sankey. Principia 23(1): 137-8.

Sankey, H. 2019. To Believe is to Believe True. Principia 23(1): 131-6.

\section{Notes}

${ }^{1}$ I am grateful to Greg Restall for comments and discussion. 